\title{
Litho-Structural Analysis of the Jarawa Complex, Northcentral Nigeria
}

\author{
Ajigo, I. O*1 and Nyako, A.A. ${ }^{2}$ \\ Department of Applied Geology, Federal University of Technology, P.M.B. 704, Akure , Nigeria ${ }^{1}$ \\ Upper Niger River Basin Development Authority, Kaduna, Nigeria ${ }^{2}$ \\ *Corresponding author
}

\begin{abstract}
The Jarawa Younger Granite Complex of Northcentral Nigeria is part of a larger belt of the Jurassic Younger Granite suite of Northern Nigeria. They are intruded into older Basement Complex rocks and are therefore structurally controlled by the pre-existing structures in the basement. Though this area is interesting in terms of geology and tectonic setting, detailed geological and structural interpretation of features in the area is lacking due to limited accessibility occasioned by the rugged/hilly nature of the terrain. Principal Component Analysis (PCA), Minimum Noise Fraction (MNF) and Band Ratio (BR) techniques were applied on Landsat 8 data for lithological discrimination while for structural interpretation, filtering techniques of edge enhancement and edge detection were applied on Digital Elevation Model (DEM) acquired by Shuttle Radar Topographic Mission (SRTM) sensor. The PCA, MNF and BR were useful for preliminary lithological and structural discrimination between different rock units in the area. For structural interpretation, DEM was used to generate shaded relief model and edge maps which enable detailed structural interpretation. Geologic fieldwork was further conducted to validate structures and units identified from image processing. Field investigations revealed five litho-textural units including Basement Complex, Hornblende-BiotiteGranite, Biotite-Microgranite, Jarawa Biotite-Granite and Jarawa Biotite-Microgranite. Foliations observed at the contact between the Younger Granite Complex and the Basement complex averagely trend NE-SW; the Rafin Jaki Granite Porphyry Dyke which range in size from $0.3-0.9$ meters is seen to harbour xenoliths of older Basement rocks mostly at the contact between the two. Joints and veins in the Jarawa biotite granite, biotite micro granite, dolerite dykes and Rafin jaki granite porphyry show a dominant trend of NW-SE; joints and veins in the hornblende biotite granite and migmatite gneisses show a dominant trend of NNE-SSW, hornblende granite porphyry shows a NE-SW trend and the Jarawa microgranite shows N-S, ENE-WSW dominant trend. The later rocks have a dominant trend of NW-SE with the exception of the Jarawa microgranite that is almost in alignment with the earlier rocks and the rocks of the basement which show a NNE-SSW dominant trend. The dominant trend of the basement; NNE-SSW, and the NWSE, NE-SW, N-S, and ENE-WSW of the granitic rocks within the study area correspond with the major structural directions of N-S, NE-SW, NW-SE, NNE-SSW and ENE-WSW of the Basement Complex and Younger Granite Ring Complex. These results have important implications in terms of regional tectonics and geological mapping as well as mineral exploration and geotechnics.
\end{abstract}

Keywords: Jarawa, PCA, Dyke, SRTM, Remote sensing

\section{INTRODUCTION}

The area of study falls within the Maijuju sheet 138 , covering an area of about $225 \mathrm{~km}^{2}$ and bound by latitude $10^{\circ} 00$ ' and $9^{0} 45^{\prime} \mathrm{N}$ and longitude $9^{0} 0 \mathrm{E}^{1}$ and $9^{0} 15^{\circ} \mathrm{E}$, located in Jos-East L.G.A of Plateau State, Nigeria (Fig. 1). The Jarawa Complex has experienced post-genetic events of metasomatism and tectonism, prior the emplacement of the dikes and may directly or otherwise, linked to mineralization in the area (Nyako et al 2014), hence the need to evaluate regional tectonic history of the area, using remote sensing as an aiding tool.

Geological field mapping and subsequent microscopic investigation of materials such as minerals, rocks ores etc. in transmitted (or reflected light) remains one of the classic and indispensable mineralogical methods of analysis. Polarized-light microscopy provides a non-destructive way to identify solid substances with relatively high spatial resolution, while phases can be studied within their textural framework. It also allows an estimate of chemical compositions and provides clues to the history of formation of the rocks, using specific textural characteristics (structures, fabric, phase relationships, reaction textures).

Remote sensing involved acquisition and use of relevant satellite data such as Land-Sat and other remotely acquired imageries which have been used extensively in the mineral exploration industry predominantly for the delineation of 


\section{International Advanced Research Journal in Science, Engineering and Technology}

Vol. 6, Issue 1, January 2019

metalliferous deposits (Airo and Loukola-Ruskeeniemi, 2004). It application ranges from mineral exploration (Murphy, 2007), structure mapping and rock characterization (Telford et al., 1990). Recent advances in technology have substantially increased the accuracy and resolution of these techniques so that they can be used to provide useful enhanced information on lithology and geological structures.

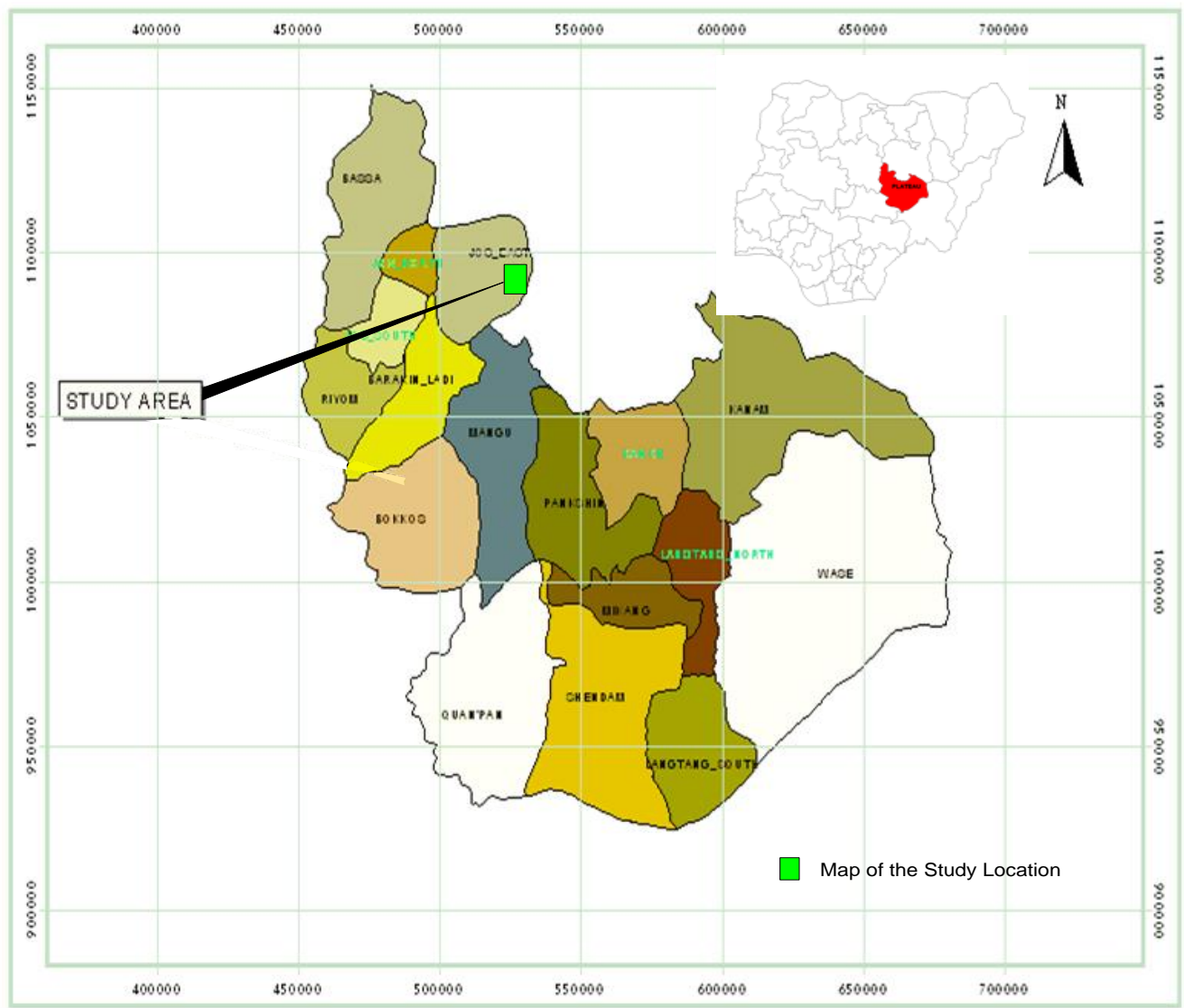

Figure 1: Geographical map of plateau state showing the location of the study area.

\section{REGIONAL GEOLOGIC SETTING}

Jarawa Complex is one of the Nigerian Younger Granite suits of rocks which are Mesozoic (Triassic to Jurassic i.e. $310 \mathrm{Ma}-140 \mathrm{Ma}$ ) make up about 53 high level, non orogenic-volcanic granitic ring complexes, (Fig. 2). The outcrop pattern ranges from circular and concentric to irregular shape. They decrease in age southward from Air (Triassic) in Niger Republic to Afu (Jurasic) in Nigeria (310Ma-140Ma) and are intrusive into the Basement Complex (Bowden et al., 1973). Based on the dominant minerals present, the granites are classified into three viz: Hornblende-pyroxenefayalite granite, Biotite granites and Riebekite granite. Other associated rock types consist of syenites, gabbros, microgabbros and dolerites (Macleod et al., 1971).

The Jarawa Younger Granite Complex consists of only two major intrusions; an-early hornblende-biotite-granite and a later biotite-granite (Berridge et al., 1971). Both of these phases are succeeded by closely related biotite-microgranites. The hornblende-biotite-granite defines the eastern and southern perimeter of the Jarawa ring-structure and also forms the two radially arranged masses of the North Jarawa and Fusa Hills. It is closely related to the Neils Valley graniteporphyry and the succeeding biotite granite so that the Jarawa cycle appears to have been contemporaneous with part of the early granite cycle of the Jos-Bukuru complex. The Jarawa-biotite-granite constitutes the main part of the wellexposed dissected plateau of the South Jarawa hills with a notably high degree of exposure.

Within the Mesozoic Younger Granites, gems (emerald and sapphire) occur in roof zones and greisens (Nyako et al, 2014). The Jarawa Complex being a part of these Younger Granite series was reported by Berridge et al (1971) to be highly mineralized in topaz and other minerals like cassiterite, wolframite, molybdenite and helvite. The gem deposits found in the area are topaz and quartz, and are seen to occur exclusively with cassiterite. 


\section{International Advanced Research Journal in Science, Engineering and Technology}

Vol. 6, Issue 1, January 2019

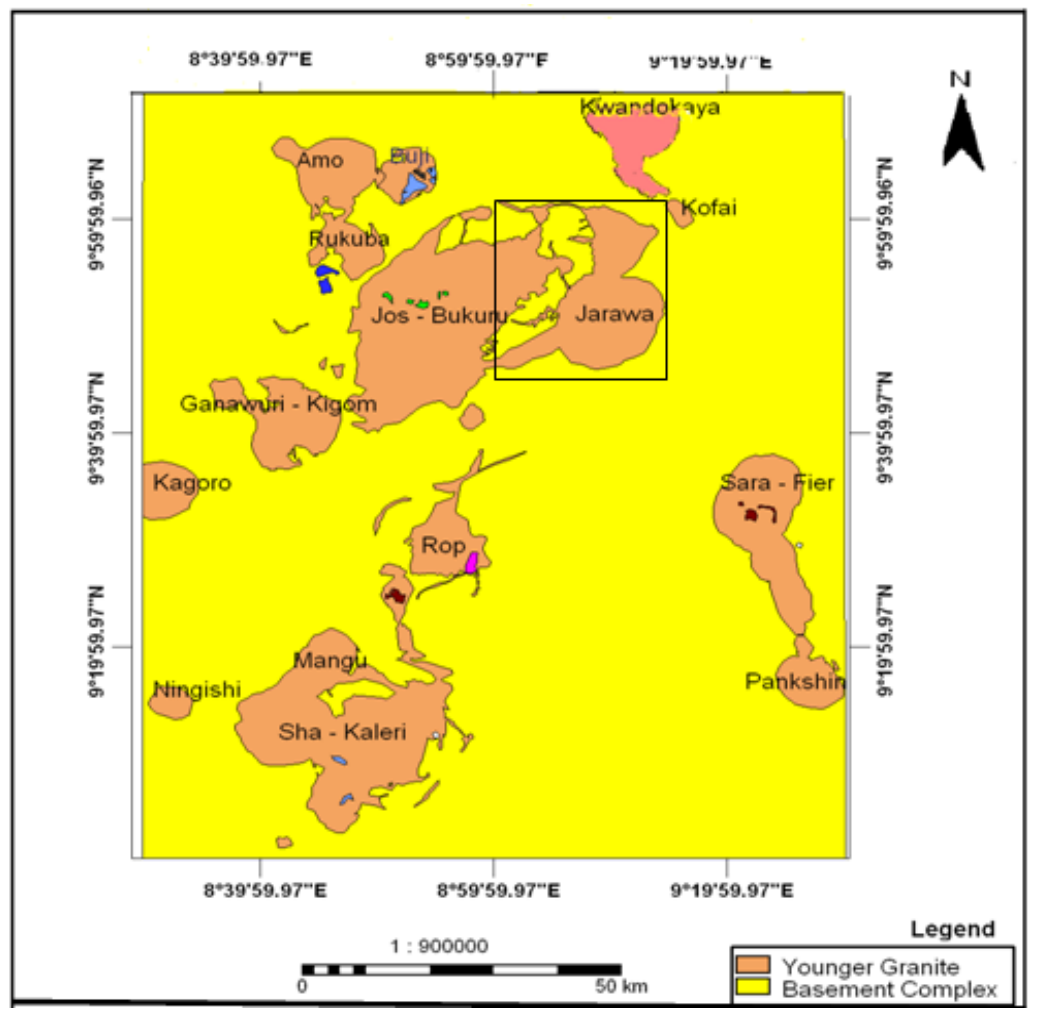

Figure 2: Jarawa Complex within the Younger Granite province of Jos Plateau.

\section{MATERIALS AND METHODS}

This study started with acquisition of maps and photo-satellite images and followed by detailed field survey where field data and bed-rock samples were collected randomly from available outcrops in the area at relatively close intervals. For this study, Shuttle Radar Topographic Mission (SRTM) Digital Elevation Model (DEM) data (Fig. 3a) with spatial resolution of $30 \mathrm{~m}$ (1 Arc-Second) and Landsat 8 image (Path/Row-190/055) covering the study area (Fig. 3b) were used. The data used were projected to WGS 1984 UTM Zone 31 N. Several pre-processing techniques were applied on Landsat 8 data before further image processing procedures. The pre-processing techniques include; conversion to Top of the Atmosphere (ToA) reflectance, sun angle correction and layer stacking. Furthermore, image processing techniques such as principal component analysis (PCA), False-Colour Composition (FCC) and Minimum Noise Fraction (MNF) were applied to the Landsat 8 data to enable lithological discrimination. For structural interpretation, filtering and edge detection techniques were applied on DEM to delineate structural features in the study area.

Reconnaissance survey which is a preliminary field investigation was first carried out followed by a more detailed systematic geological mapping on scale of 1:50,000. This exercise involves the use of topographic map as a guide to locate the outcrops present in the study area. The topographic map was divided into grids to aid mapping and accessibility to different locations. Observations made on each outcrop include megascopic identification of minerals present in the rock outcrops, mineral composition, texture, degree and pattern of weathering, color of fresh rock surface, and measurement of strike and dip values. Equipment used includes compass clinometer, field note book, topographic or base map, ruler, protector, pencils (including colored pencils and markers), hand lens, digital camera, geologic hammer, chisel, sample bags, measurement tape etc.

\section{RESULTS AND DISCUSSION}

\section{Geology}

The Jarawa Complex consists of only two major intrusions: an early hornblende biotite-granite and a later biotitegranite. Both these phases were succeeded by closely related biotite-mircogranites. The hornblende-biotite-granite defines the eastern and southern perimeter of the Jarawa ring-structure and also forms the two radially arranged masses of the north Jarawa and Fusa Hills. Field investigations revealed five litho-textural units including Basement Complex, Hornblende-Biotite-Granite, Biotite-Microgranite, Jarawa Biotite-Granite and Jarawa Biotite-Microgranite, (Fig. 8). The Basement Complex rocks cover about thirty percent (30\%) of the study area and occupy the lowland areas covered by soil due to the intense weathering and erosion that have affected them; a few exposures are found along steam channels and as scattered boulders. The hornblende - biotite - granite is strongly resistant to erosion producing nearly 


\section{International Advanced Research Journal in Science, Engineering and Technology}

Vol. 6, Issue 1, January 2019

$1240 \mathrm{~m}$ of relief in the north Jarawa Hills, but are readily prone to weathering. This coarse-grained intrusion occupies about 150.2 sq. kilometers in the Jarawa and Fusa hills. Contacts between the hornblende - biotite-granite and the basement show great local variation in attitude and are frequently braided especially along the south - east margins of the Fusa and North Jarawa Hills. The Hornblende-biotite-granite, the preceding granite-porphyry and the succeeding Jarawa biotite-granite are believed to be in concord and have vertical contacts. Large irregular intrusions and lenses of biotite-microgranite occur within the coarse hornblende-biotite granite of the North Jarawa hills and the central Jarawabiotite-granite which is the last phase of the group of intrusions associated with the Neil's valley ring-structure. The microgranite has a groundmass in which the perthite tends to be interstitial to the granular quartz. It sometimes has a granophyric texture especially in the vicinity of the phenocrysts, which are cryptoperthite, and these features give the rock a similarity to the porphyritic phase of the coarse-grained granite. In the microgranite biotite, is the sole ferromagnesian silicate and there is some replacement of primary feldspar by the albite. The Jarawa biotite-granite has an approximately circular outcrop occupying about 165.8 sq. kilometres. It constitutes the main part of the wellexposed, dissected plateau of the South Jarawa Hills. The rock type is less resistant to erosion than the Hornblende biotite-granites around it, but the degree of exposure is notably higher. The intrusion appears to be of cylindrical form, since its outer contacts are generally simple in plan and near vertical in attitude. Evidence from lithological variation, notably from widely distributed quartz-filled vughs and large-scale xenolithic blocks (figure 6), suggest that the intrusion is exposed near its roof level. A high degree of mineralization, with cassiterite, wolfram, molybdenite, helvite and topaz, (figure7) is further evidence that the present erosion surface is close to the roof of the intrusion. The Jarawa biotite-microgranite forms three small irregular intrusions and numerous minor dykes, pods and veins which cut the Jarawa biotite-granite, and to the north of maijuju, locally transgress the contact with the Hornblende-biotite-granite. The largest individual intrusion of this rock occurs in Zigam, at the centre of the south Jarawa hills. The contacts that are exposed are very irregular in detail, with marginal veins and sheets and occasional xenoliths of the biotite-granite wall-rock. This rock is noticed to be very homogenous, with widely spaced feldspar phenocrysts in a sugary groundmass. In thin section, the free albite appears as interstitial plates as well as large crystals replacing the perthites. The large euhedral phenocrysts tend to resist alteration.

\section{Structure}

Significance of structures of this area cannot be overemphasized as they are found to be associated with mineralization of fluorite topaz, cassiterite and much more (figure 7). Lineament features were extracted from processed Satellite images to show the structural trend of the study area (Figure $3 \& 4$ ). Joints, dykes, flow structures and veins were observed in the field as the structural features in the study area. Mainly, foliations were observed in the basement complex rocks. Measurements were carried out on the linear structures and result shows that they display variable trends. Foliations were observed in the migmatite gneisses at the contact between the Younger Granite Complexes and the Basement complex. Averagely, they trend NE-SW (fig. 5).

In the study area, veins are predominantly quartz and aplitic veins. The quartz veins are noticed more in the Hornblende-biotite-granite ranging in thickness from $>1$ to $2 \mathrm{~cm}$. The aplite veins occur more frequent in the Jarawabiotite-granite, rarely with veins of quart-feldspar-pegmatites that range in thickness from 10 to $40 \mathrm{~cm}$. Within the basement are noticed more of the quartz veins. The trends of these joints and veins are represented in the Rose plots (Fig. 5)

Dykes as observed, are basic as in the southern Jarawa hills. They range in scale from minute branching veins (30$40 \mathrm{~cm}$ ) within granite joints to straight dykes up to $3.5 \mathrm{~m}$ wide and almost a kilometer long. The Rafin Jaki Granite Porphyry dyke in particular is acidic with a basic margin. It is about $10 \mathrm{~m}$ wide at the weathered basement west of the Jarawa Complex and runs in a NW-SE direction.

Net-veins constitute a network of fluorite intrusions injected under considerable high pressure penetrating the highly fractured basement that is now weathered around the Rafin Jaki Granite Porphyry, thus forming a network. They are linked at intervals by cross-connecting veins that have sharp and regular contacts. This indicates that the basement was highly fractured and unaffected by weathering during the fluorite intrusion. The veins range in thickness from 2 to $40 \mathrm{~cm}$. Xenoliths observed in the field are of basement rock bodies enclosed within the Rafin Jaki Granite Porphyry Dyke and range in size from 0.3 - 0.9 meters, and even above it. They appear to be of local origin (Fig. 6).

From the structural studies performed and presented in the rose diagrams, it is revealed that the joints and veins in the Jarawa biotite granite, biotite micro granite, dolerite dykes and Rafin jaki granite porphyry show a dominant trend of NW-SE (Fig. 9). The joints and veins in the hornblende biotite granite and migmatite gneisses show a dominant trend of NNE-SSW, hornblende granite porphyry shows a NE-SW trend and the Jarawa microgranite shows N-S, ENE-WSW dominant trend. Thus, it can be seen that the later rocks have a dominant trend of NW-SE with the exception of the Jarawa microgranite that is almost in alignment with the earlier rocks and the rocks of the basement which show a NNE-SSW dominant trend. The dominant trend of the basement; NNE-SSW, and the NW-SE, NE-SW, N-S, and ENEWSW of the granitic rocks within the study area correspond with the major structural directions of N-S, NE-SW, NWSE, NNE-SSW and ENE-WSW of the Basement Complex and Younger Granite Ring Complex (Rahaman et al, 1988, Turner, 1989). 


\section{International Advanced Research Journal in Science, Engineering and Technology}

Vol. 6, Issue 1, January 2019
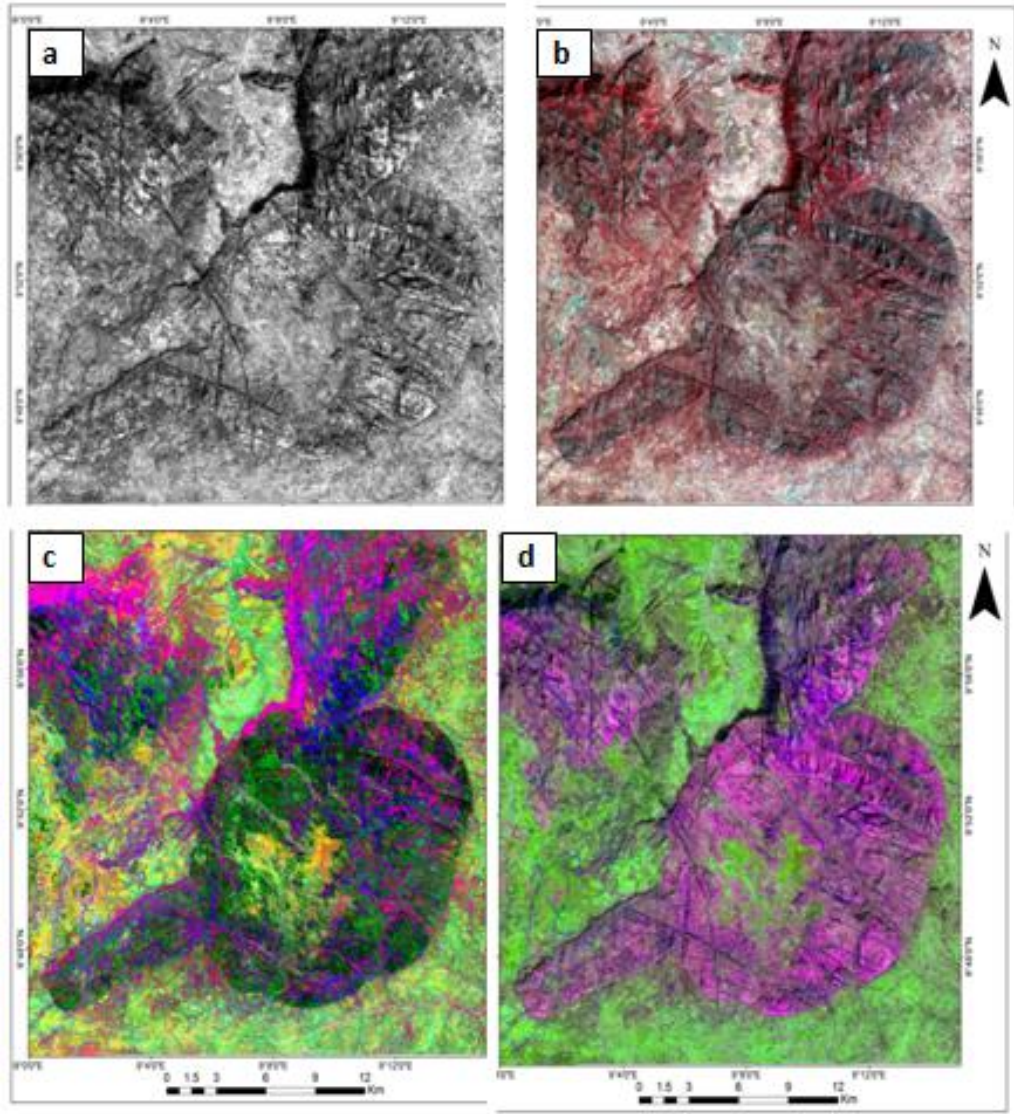

Figure 3: LandSat image of the study area displayed as: (a) Band 7 (b) false colour composite of Red, Blue and Green; (c) Principal component analysis (PCA); (d) Minimum noise fraction (MNF)
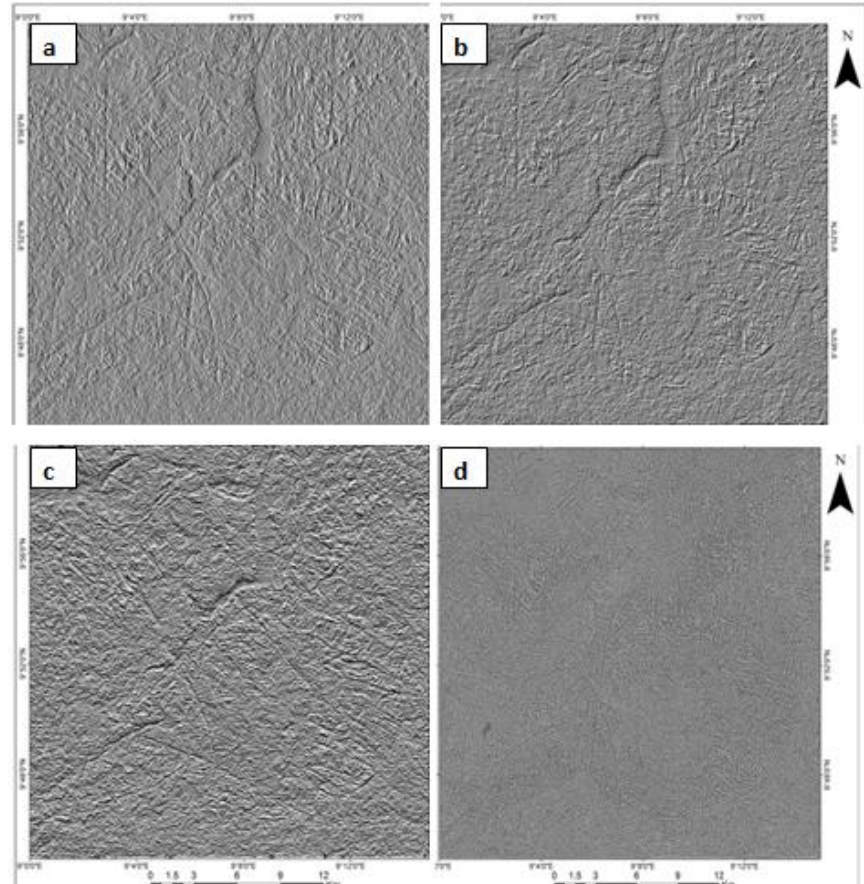

Figure 4: Directional filters to highlight fractures in different directions: (a) $0^{\circ}$ filter (b) $45^{\circ}$ filter (c) $90^{\circ}$ filter (d) Laplacian filter. 


\section{International Advanced Research Journal in Science, Engineering and Technology}

Vol. 6, Issue 1, January 2019

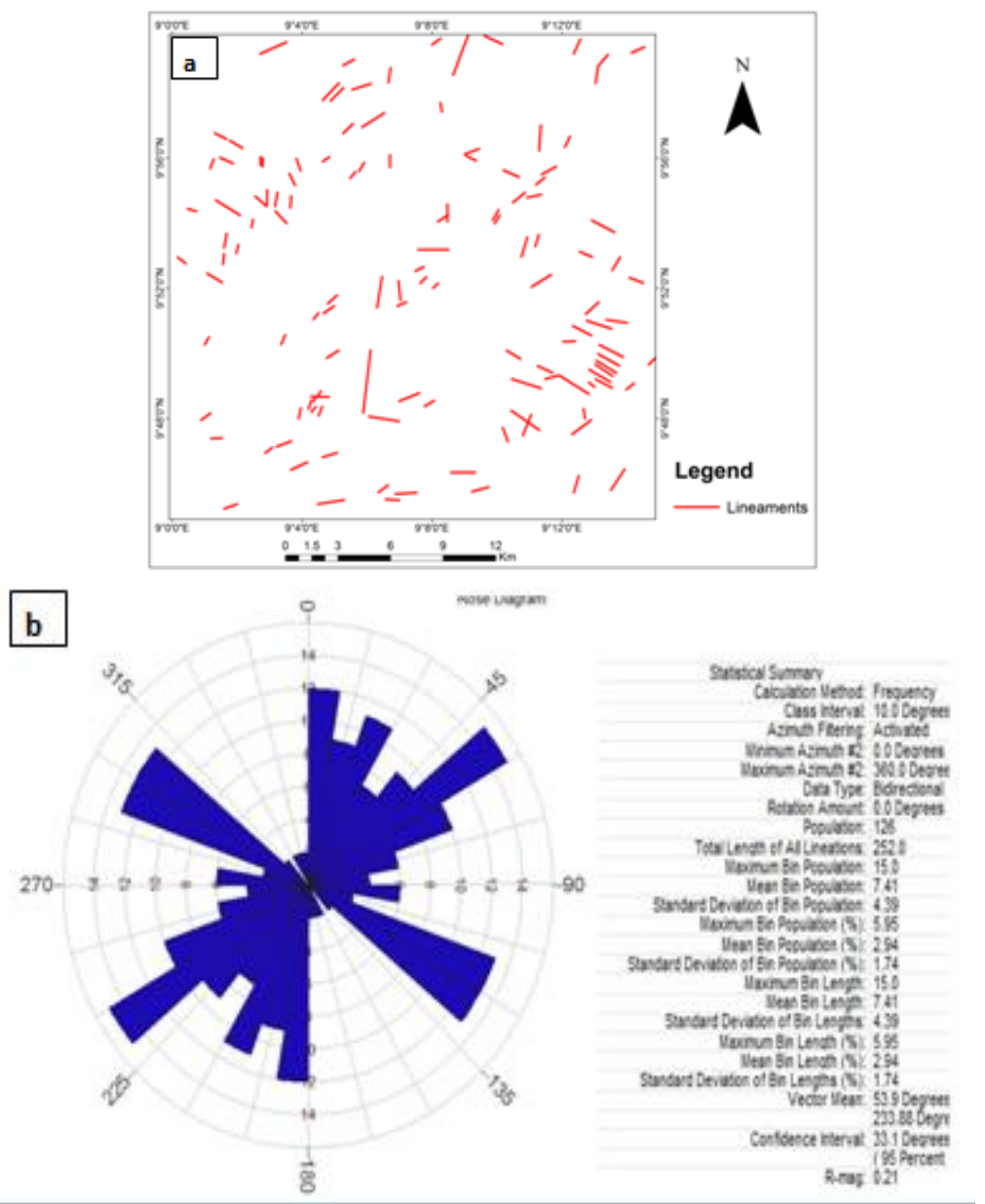

Figure 5: (a) Lineament map derived from remote sensing data of the study area;

(b) Rose diagram showing length and frequency of lineament from Remote sensing data
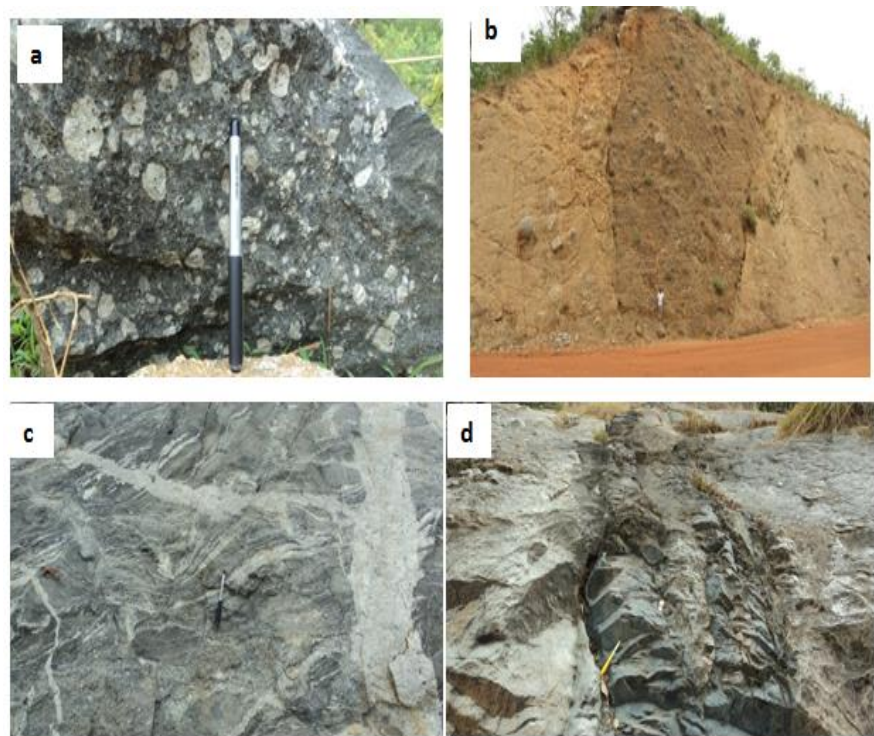

Figure 6: (a) specimen of Rafin jaki granite porphyry with large Phenocrysts of feldspar together with small phenocrysts of quartz in a groundmass of feldspar, quartz and dark minerals; (b) A cross-section of the Rafin jaki granite porphyry with enclosed xenoliths of basement rocks; the country rock is a weathered basement; (c) network of quartzitic veins in migmatite gneiss within the study area; (d) A dolerite vein within a medium grained granitic rock in the study area. 


\section{International Advanced Research Journal in Science, Engineering and Technology}

Vol. 6, Issue 1, January 2019
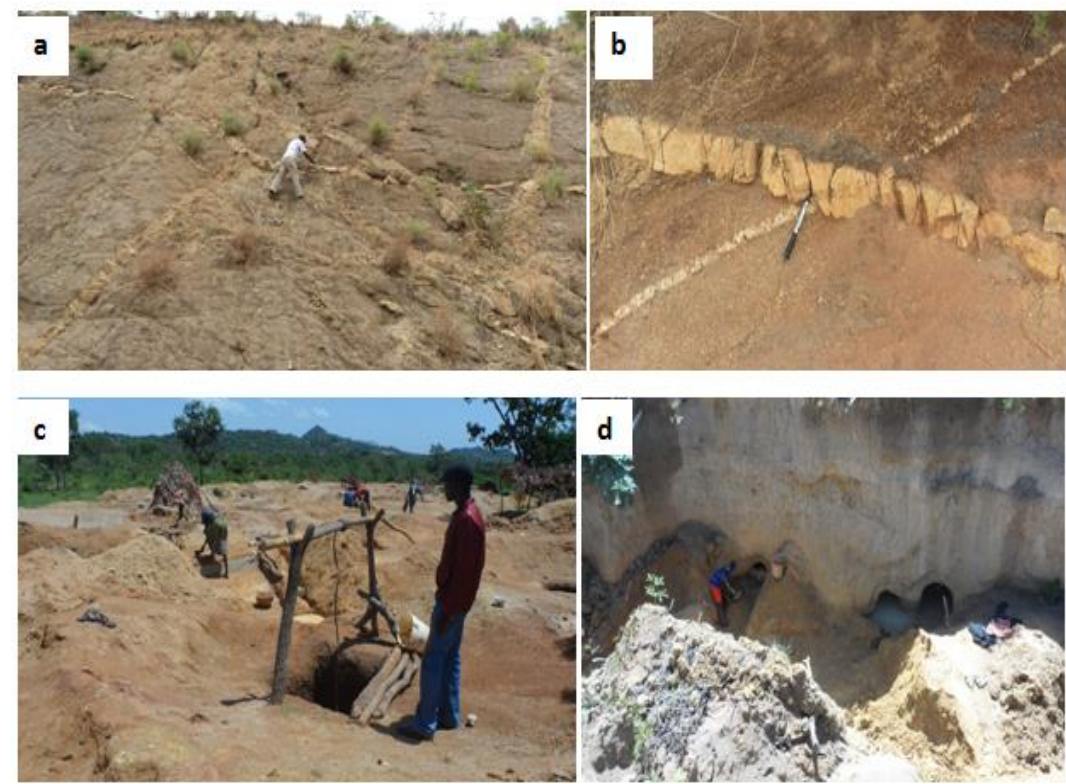

Figure 7: (a) A fluorite net-vein structure within the weathered basement in the study area; (b) A thinner net-vein structure of fluorite; (c) Local underground mining (loto mining) of topaz and cassiterite within the Jarawa-biotitegranite alluvium at Zebir-Nabar; (d) local underground mining (loto mining) of tapaz in Zabir-Nabar, a part of the study area within the Jarawa-biotite-granite.

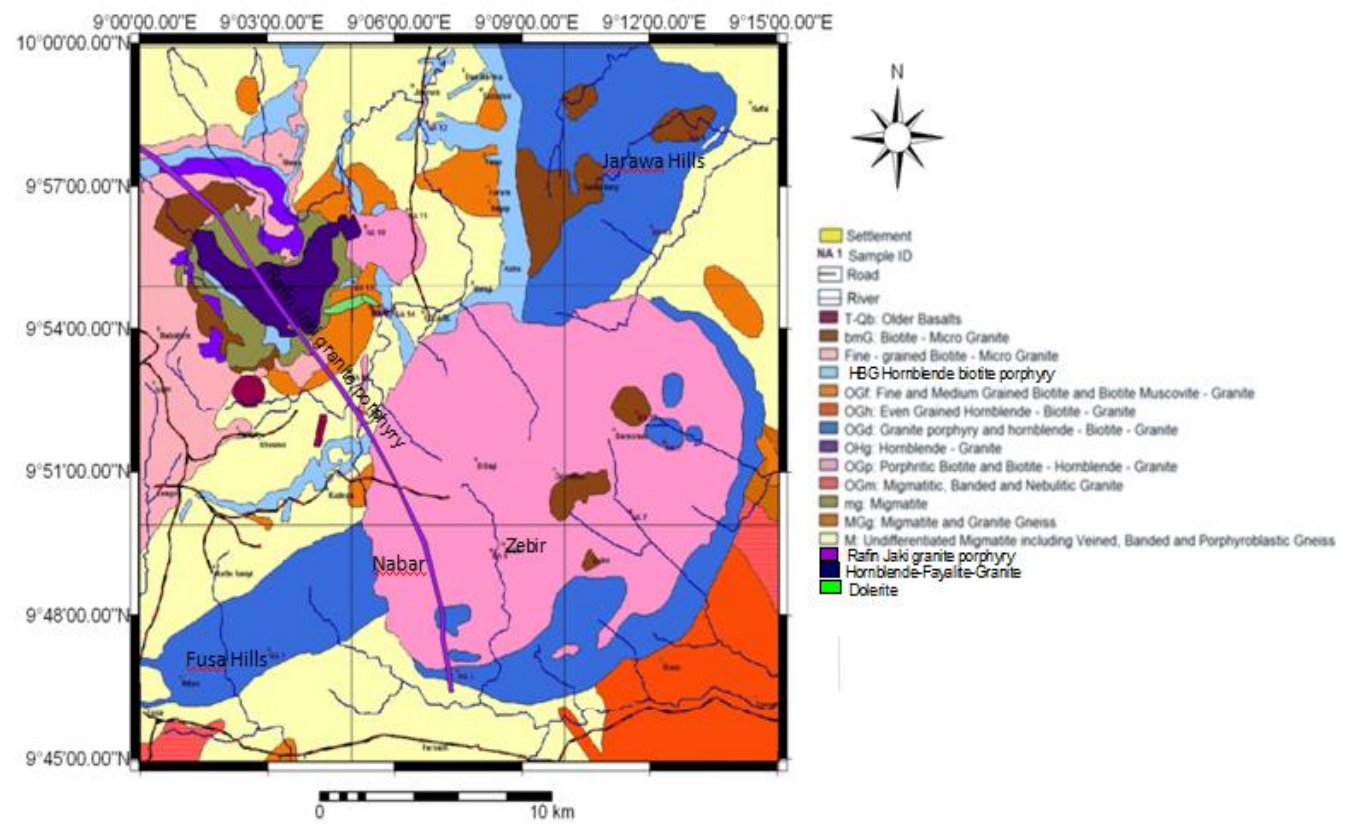

Figure 8: Geological Map of the Study Area. 


\section{International Advanced Research Journal in Science, Engineering and Technology}

Vol. 6, Issue 1, January 2019

Table 1: Strike of joints/veins measures on (a) Migmatite gneisses; (b) Jarawa biotite granite; (c) Jarawa biotite microgranite; (d) hornblende-biotite-granite; (e) hornblende-biotite-porphyry; (f) Jarawa-microgranite; (g) dolerite dykes; (h) Rafin jaki granite porphyry.

\begin{tabular}{|c|c|c|c|c|c|c|c|c|c|}
\hline S/No & \multicolumn{8}{|c|}{ Strike Values $\left({ }^{0}\right)$ of lineaments for different rock units } & \\
\hline & $\mathbf{a}$ & b & c & d & e & f & g & $\mathbf{h}$ & \\
\hline 1 & 28 & 48 & 60 & 20 & 18 & 70 & 130 & 8 & \\
\hline 2 & 27 & 142 & 60 & 30 & 60 & 130 & 130 & 148 & \\
\hline 3 & 22 & 82 & 76 & 32 & 20 & 134 & 130 & 160 & \\
\hline 4 & 24 & 150 & 8 & 22 & 48 & 61 & 130 & 160 & \\
\hline 5 & 16 & 10 & 160 & 40 & 46 & 78 & 151 & 170 & \\
\hline 6 & 20 & 150 & 160 & 35 & 14 & 10 & 151 & 60 & \\
\hline 7 & 29 & 150 & 148 & 65 & 16 & 92 & 151 & 60 & \\
\hline 8 & 36 & 150 & 148 & 80 & 8 & 136 & 155 & 54 & \\
\hline 9 & 38 & 150 & 148 & 100 & 10 & 51 & 155 & 72 & \\
\hline 10 & 42 & 150 & 148 & 99 & 56 & 64 & 155 & 168 & \\
\hline 11 & 52 & 150 & 148 & 101 & 55 & 12 & 155 & 134 & \\
\hline 12 & 54 & 156 & 80 & 120 & 58 & 10 & 155 & 142 & \\
\hline 13 & 59 & 152 & 170 & 112 & 42 & 76 & 155 & 142 & \\
\hline 14 & 74 & 88 & 1 & 82 & 42 & 66 & 8 & 158 & \\
\hline 15 & 78 & 88 & 54 & 88 & 38 & 90 & 152 & 32 & \\
\hline 16 & 72 & 88 & 72 & 105 & 34 & 72 & 152 & 32 & \\
\hline 17 & 78 & 86 & 168 & 38 & 106 & 150 & 152 & 146 & \\
\hline 18 & 62 & 161 & 134 & 46 & 120 & 46 & 152 & 146 & \\
\hline 19 & 110 & 161 & 142 & 54 & 110 & 54 & 152 & 152 & \\
\hline 20 & 125 & 161 & 142 & 47 & 88 & 86 & 120 & 146 & \\
\hline 21 & 130 & 161 & 158 & 28 & 86 & 138 & 168 & 146 & \\
\hline 22 & 132 & 154 & 148 & 36 & 68 & 136 & 168 & 146 & \\
\hline 23 & & 154 & 148 & 24 & 72 & 176 & 90 & 152 & \\
\hline 24 & & 154 & 32 & 18 & 74 & 68 & 100 & 152 & \\
\hline 25 & & 146 & 32 & 22 & 76 & 12 & 127 & 152 & \\
\hline 26 & & 146 & 146 & 78 & 78 & 12 & & 152 & \\
\hline 27 & & 146 & 146 & 46 & 64 & 10 & & 152 & \\
\hline 28 & & 146 & 146 & 58 & 64 & 40 & & 152 & \\
\hline 29 & & 160 & 146 & 75 & 170 & 86 & & 154 & \\
\hline 30 & & 160 & 146 & & & 10 & & 154 & \\
\hline 31 & & 160 & 152 & & & 152 & & 154 & \\
\hline 32 & & 160 & 152 & & & 160 & & 154 & \\
\hline 33 & & 160 & 152 & & & 154 & & & \\
\hline 34 & & 160 & 152 & & & & & & \\
\hline 35 & & 160 & 152 & & & & & & \\
\hline 36 & & 158 & 152 & & & & & & \\
\hline 37 & & 166 & & & & & & & \\
\hline 38 & & 178 & & & & & & & \\
\hline 39 & & 148 & & & & & & & \\
\hline 40 & & 168 & & & & & & & \\
\hline
\end{tabular}




\section{International Advanced Research Journal in Science, Engineering and Technology}

Vol. 6, Issue 1, January 2019

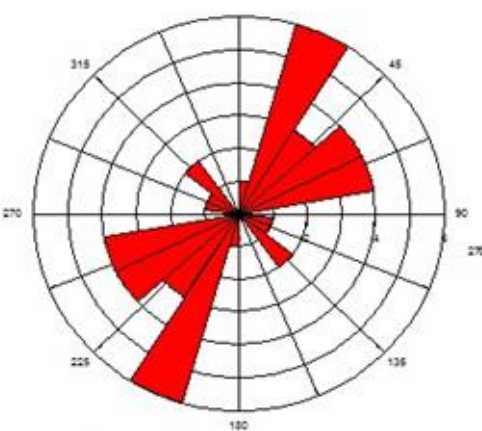

a

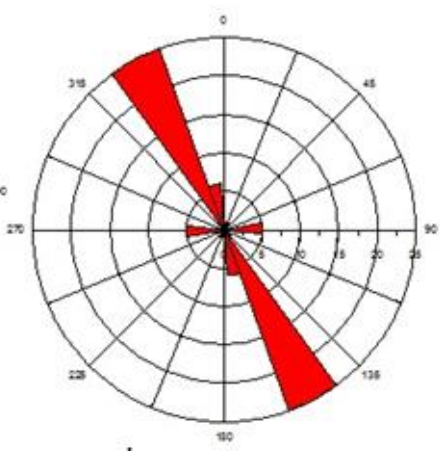

b

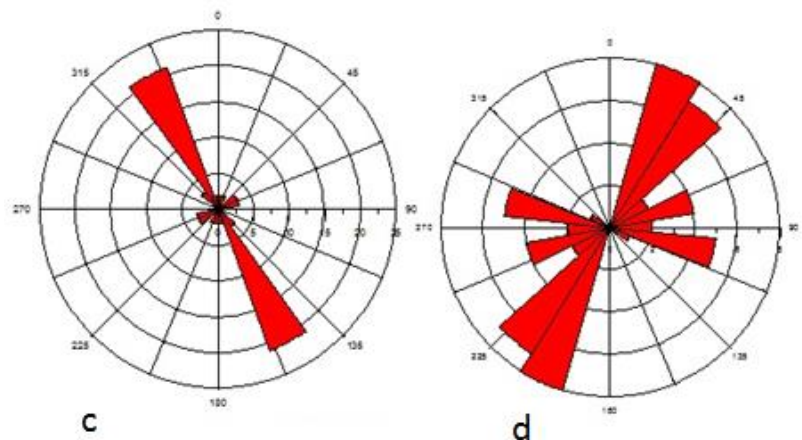

Figure 9: Rose diagram from field data showing: (a) NNE-SSW dominant trends of lineaments in the Migmatite gneisses; (b) NW-SE dominant trends of lineaments in the Jarawa biotite granite; (c) NW-SE dominant trends of lineaments in the Jarawa biotite micro-granite; (d) NNE-SSW dominant trends of lineaments in hornblende-biotite-granite.

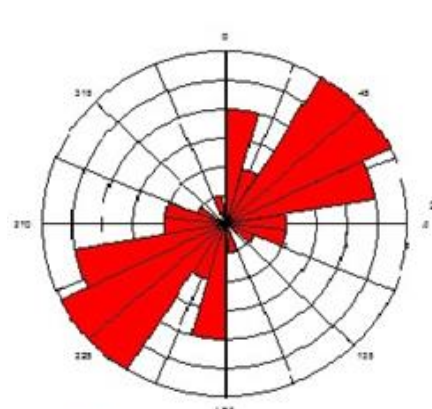

e

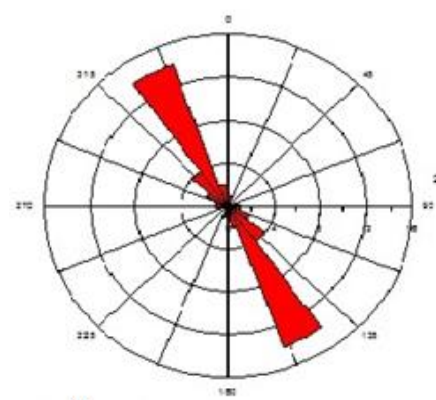

g

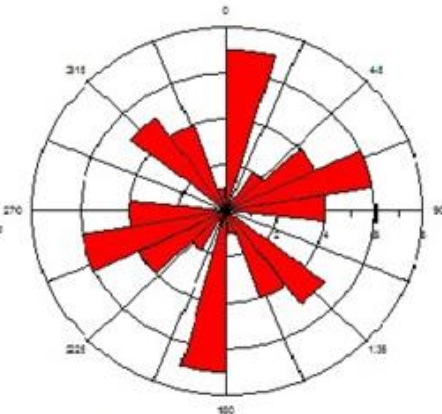

f

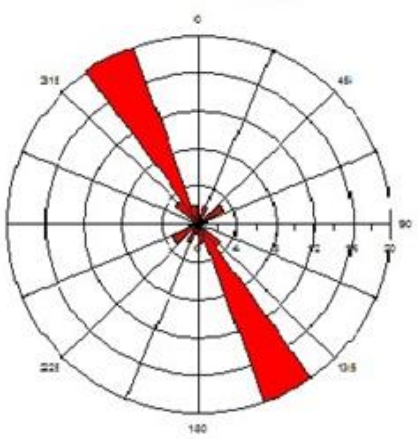

$\mathrm{h}$

Figure 9 (continued): (e) NE-SW dominant trends of lineament in hornblende-biotite-porphyry; (f) N-S, ENE-WSW dominant trends of lineaments in Jarawa-microgranite; (g) NW-SE dominant trends of lineaments in the dolerite dykes;

(h) NW-SE dominant strike lineaments in Rafin jaki granite porphyry. 


\section{International Advanced Research Journal in Science, Engineering and Technology}

Vol. 6, Issue 1, January 2019

\section{CONCLUSION}

The study area is composed of the Jarawa-biotite-granite, biotite-granite and biotite-muscovite-granite, biotitemicrogranite, jarawa-biotite-microgranite, hornblende-biotite-granite, and hornblende-biotite-porphyry, while the dolerite dikes and Rafin jaki granite porphyry dike intrude these rocks. The Jarawa Complex rocks are intrusive into the Basement complex rocks. Structures observed and measured in the field include foliations, joints, veins, net-veins, dykes and xenoliths. The major structural directions are oriented N-S, NE-SW, NW-SE, NNE-SSW and ENE-WSW which correspond with the structural trend of the Basement Complex rocks. The mineral suits identified include clinopyroxenes (augite), feldspars (plagioclase and orthoclase), hornblende, biotite, quartz, chlorite, myrmekite and accessories including titanite (sphene), zircon, iron oxide. Perthite structures of plagioclase and orthoclase feldspars were also observed. The preponderance of albite and in some cases serisite, with topaz and zircon as minor constituents confirm alteration via pneumatolysis.

\section{REFERENCES}

[1]. Abaa, S.I. (1990): Hydrothermal fluid Responsible for the Formation of Precious Minerals in the Nigerian Younger Granite province. Mineral Deposits, Spring-Verlag. Vol.26, pg 34-39.

[2]. Abdelsalam, M.G., Stern, R.J., (1999): Mineral exploration with satellite remote sensing imagery: examples from Neoproterozoic Arabian shield. J. Afr. Earth Sci. 28, 4a.

[3]. Abrams, M.J., Brown, D., Lepley, L., Sadowski, R., (1983): Remote sensing for porphyry copper deposits in southern Arizona. Econ. Geol. 78 , $591-604$.

[4]. Adubok A.S (2008): Evolutionary Trend of the Jarawa Younger Granite Ring Complex, Jos Plateau Central Nigeria. Science World Journal Vol.3.

[5]. Adubok, A.S. (1987): Mineralogy, Geo-chemistry and Mode of emplacement of the Jarawa Younger Granite Ring Complex, Jos Plateau, Central Nigeria. B.Sc Thesis, University of Jos, Nigeria.

[6]. Airo M L, Loukola-Ruskeeniemi K (2004): Characterization of sulphide deposits by airborne magnetic and gamma-ray responses in eastern

[7]. Finland. Ore Geology Reviews, 24 (1):67-84.

[8]. Anifowose, A.Y.B., Borode, A.M., (2007): Photogeological study of the fold structure in Okemesi area, southwestern Nigeria. J. Min. Geol. 43 (2), 125-130.

[9]. Ayodele, O.S., Odeyemi, I.B., (2010): Analysis of lineaments extracted from Landsat TM imagery of Okemesi area, southwestern Nigeria. Indian J. Sci. Technol. 1, 34-38.

[10]. Berridge, N. G.; Buchanan, M. S.; Macleod, W.N.; Turner, D.C.; Berridge, N. G. \& Black, R. (1971): The Geology of the Jos Plateau Younger

[11]. Granites Complexes, Bull. Geol. Survey of Nigeria, 2 (32): 67-106.

[12]. Bowden, P and Van-Breemen O., (1973): Sequential Age Trends for Some Nigerian Mesozoic Granites. Nature, Physical Science. Vol. 243 pp 9-11.

[13]. Buchanan, M.S, Macleod, W.N., Turner, D.C., Berridge, N.G. and Black, R. (1971): The Geology of the Jos Plateau. G.S.N Bull.32, Vol.2.

[14]. Didier, J. (1973): Granites and their enclaves. In: Development in Petrology. Vol. 3, Elsevier Scientific Publishing Company.

[15]. Drury, S.A., (1987): Image Interpretation in Geology, first ed. Allen and Unwin, London.

[16]. Drury, S.A., (2001): Image Interpretation in Geology, third ed. Nelson Thornes, Cheltenham,UK.

[17]. Ekwueme, B.N. (1993): An Easy Approach to Igneous Petrology, University of Calabar Press pp. 19-153.

[18]. Elebe, B. O. (1990): Geology and Mineral Processing of Alluvial Deposits - 'Columbite', Jos Plateau; unpublished B.Sc Thesis, University of Jos, Nigeria

[19]. Etsuo Uchida, Sho Endo and Mitsutoshi Makino (2003): Relationship Between Solidification Depth of Granitic Rocks and Formation of

[20]. Hydrothermal Ore Deposits. Department of Resources and Environmental Engineering, Waseda University, Shinjuku, Tokyo, Japan. Resource Geology Vol. 57, No. 1: 47-56.

[21]. Exelis VIS, (2000): Some details on ENVI's Principal Components algorithm. Retrieved from

[22]. http://www.exelisvis.com/Company/PressRoom/TabId/190/ArtMID/786/ ArticleID/2765/2765.aspx

[23]. Gad, S., Kusky, T., (2002): Lithological mapping in the Eastern Desert of Egypt, the Barramiya area, using Landsat thematic mapper (TM). J. Afr.

[24]. Earth Sci. 44, 196-202.

[25]. Garba, I. (1988): Introduction to Geology and Mineral Deposits of Nigeria, Ganuwa Publishers Series, Zaria.

[26]. Hatch, T. H., Wells, A.K. and Wells M.K., (1972): petrology of the Igneous Rocks. Thirteenth Edition. George Allen and Unwin Ltd.

[27]. Hung, L.Q., Batelaan, O., De Smedt, F., (2005): Lineament extraction and analysis, comparison of Landsat ETM and ASTER imagery: case

[28]. study — suoimuoi tropical karst catchment, Vietnam. In: In: Ehlers, Manfred, Michel, Ulrich (Eds.), Remote Sensing for Environmental Monitoring, Volume V: GIS Applications and Geology. vol. 5983, p. 12. Proceedings of SPIE.

[29]. Karnieli, A., Meisels, A., Fisher, L., Arkin, Y., (1996) Automatic Extraction and Evaluation of Geological Linear Features from Digital Remote Sensing Data Using a Hough Transform.

[30]. Kaufmann, H., (1988): Mineral exploration along the Aqaba-levent structure by use of Landsat TM data; concepts, processing, and results. Int. J. Remote Sens. 9, 1639-1658.

[31]. Imoekparia, E.G. (1985): Geochemical Evolution of the Jarawa Younger Granite complex, Geological Magazine 122 (2):163- 173, Printed in Great Britain.

[32]. Macleod, W.N., Turner, D.C. and Waight, E.P. (1971): The Geology of Jos Plateau. Geol. Sun- Nigeria, Bull. No. 32. Vol. 2. Pg 160.

[33]. Murphy BS (2007): Airborne geophysics and the Indian scenario. J. Ind. Geophysics Union, 11 (1), 1-28.

[34]. Nyako, A.A, Ajigo, I.O., and Ashano, E.C. (2014): Trace elements as pathfinders for gemstone deposits: a case study of Jarawa and eastern part of Shere complex, north central Nigeria. International Journal of Research in Earth \& Environmental Sciences. Vol. 1, No.3 pp 17-28.

[35]. Odeyemi, I.B., (1993): A comparative study of remote sensing images of structure of the Okemesi fold belt, Nigeria. ITC Neth. J. 1, 77-81.

[36]. Ogezi, A. E. (1986): Mineral Raw Materials and the Nigerian Economy. University of Jos Postgraduate Open Lecture, Unpublished.

[37]. Rahaman, M.A. (1988): Recent advances in the study of Basement Complex of Nigeria: In Precambrian Geology of Nigeria (edited by Nigerian Geological Survey), Pg. 11-43.

[38]. Shuaibu, A. (1985): Distribution of Trace Elements in Orthoclase of the Jarawa Ring Complex. B.Sc Thesis, University of Jos, Nigeria

[39]. Telford WM, Geldart LP, Sheriff RE (1990): Applied Geophysics ( $2^{\text {nd }}$ Edition ed.).Cambridge University Press.

[40]. Turner, D.C. (1989): Structure and Petrology of the Younger Granite Ring Complexes. In C.A. Kogbe (Ed). Geology of Nigeria. Second Revised Edition-Rock View Ltd. Jos. Pp 175-190. 